\title{
New and regenerated production in relation to the microbial loop in the NW Mediterranean Sea
}

\author{
Johanne-Sophie Selmer ${ }^{1}$, Christine Ferrier-Pages ${ }^{2}$, Christiane Cellario ${ }^{2}$, \\ Fereidoun Rassoulzadegan ${ }^{2}$
}

\author{
${ }^{1}$ Dept of General and Marine Microbiology, University of Göteborg, Carl Skottsbergs Gata 22, S-413 19 Göteborg, Sweden \\ ${ }^{2}$ Station Zoologique, BP 28, F-06230 Villefranche-sur-Mer, France
}

\begin{abstract}
Nitrogen transformations were investigated in the Bay of Villefranche-sur-Mer, on the south coast of France, during autumn 1990 and spring 1991, using ${ }^{15} \mathrm{~N}$-isotope techniques on sizefractionated sea water samples. Besides measuring uptake of ammonium and nitrate, and ammonium regeneration, the biological composition in 4 size fractions $<1 \mu \mathrm{m}_{1}<10 \mu \mathrm{m}_{i}<100 \mu \mathrm{m}$ and unfractionated water) was determined. The plankton was dominated by pico- and nanoplankton, of which the cyanobacteria and nanoflagellates dominated the autotrophs. Heterotrophic bacteria constituted 70 and $30 \%$ of the $<1 \mu \mathrm{m}$ and $<10 \mu \mathrm{m}$ fractions, respectively. During spring, ammonium uptake rates were low and nitrate uptake rates often negligible, resulting in a total dominance (98 to $100 \%$ ) of regenerated production. In autumn, however, nitrate uptake rates were higher, with new production amounting to $34 \%$. The regenerated production was mostly accomplished by pico- and nanoplankton, especially cyanobacteria and autotrophic nanoflagellates, but also heterotrophic bacteria. When present, the ciliates accounted for the major part of ammonium regeneration, otherwise it was heterotrophic pico- and nanoflagellates. Considering the nitrogen dynamics and the plankton composition, these waters may be considered as mesotrophic.
\end{abstract}

\section{INTRODUCTION}

The microbial loop and the nitrogen dynamics in a marine ecosystem are closely coupled. Nutrients are regenerated at each grazing level of the microbial loop and are thus made available to the primary producers (e.g. Williams 1981, Azam et al. 1983), giving rise to regenerated production (Dugdale \& Goering 1967 , Eppley \& Peterson 1979).

The Mediterranean Sea is generally regarded as oligotrophic (Dugdale 1976), and should therefore be dominated by regenerated production. In contrast to other oceans, the Mediterranean Sea has long been considered as phosphorus limited (e.g. Maestrini \& Kossut 1981, Berland et al. 1988). Recently, however, it has been suggested that the phosphorus limitation is confined to the eastern part of the Mediterranean Sea, while the western part is nitrogen limited (Woodward \& Owens 1989, Krom et al. 1991a). The nitrate content in the deep water, which is formed in the eastern basin and leaves through the Strait of Gibraltar, is low com- pared to other oceans (Béthoux \& Copin-Montégut 1986, Krom et al. 1991b). As a result, the vertical advective flow of nitrate, which is the main nutrient source for new production, is low. Other nitrogenous nutrients, such as an external input of ammonium from both land and deep water, may therefore become important contributors to new production (Dugdale \& Wilkerson 1988). Consequently, it may not be possible to determine new and regenerated production using ${ }^{15} \mathrm{~N}$-based uptake studies.

The only previous ${ }^{15} \mathrm{~N}$-based studies of new and regenerated production in the NW Mediterranean Sea of which we know were performed in the Gulf of Lions (Owens et al. 1989, Woodward et al. 1990), an area adjacent to the Ligurian Sea (where the present work was undertaken, see map, Fig. 1). In the Ligurian Sea, ${ }^{15} \mathrm{~N}$-based uptake studies had never been performed before, but new production has indirectly been estimated to ca $25 \%$ as a yearly mean, and ca $40 \%$ during spring bloom (Minas et al. 1988, Fowler et al. 1991). Comparing these values with how Eppley \& Peterson 


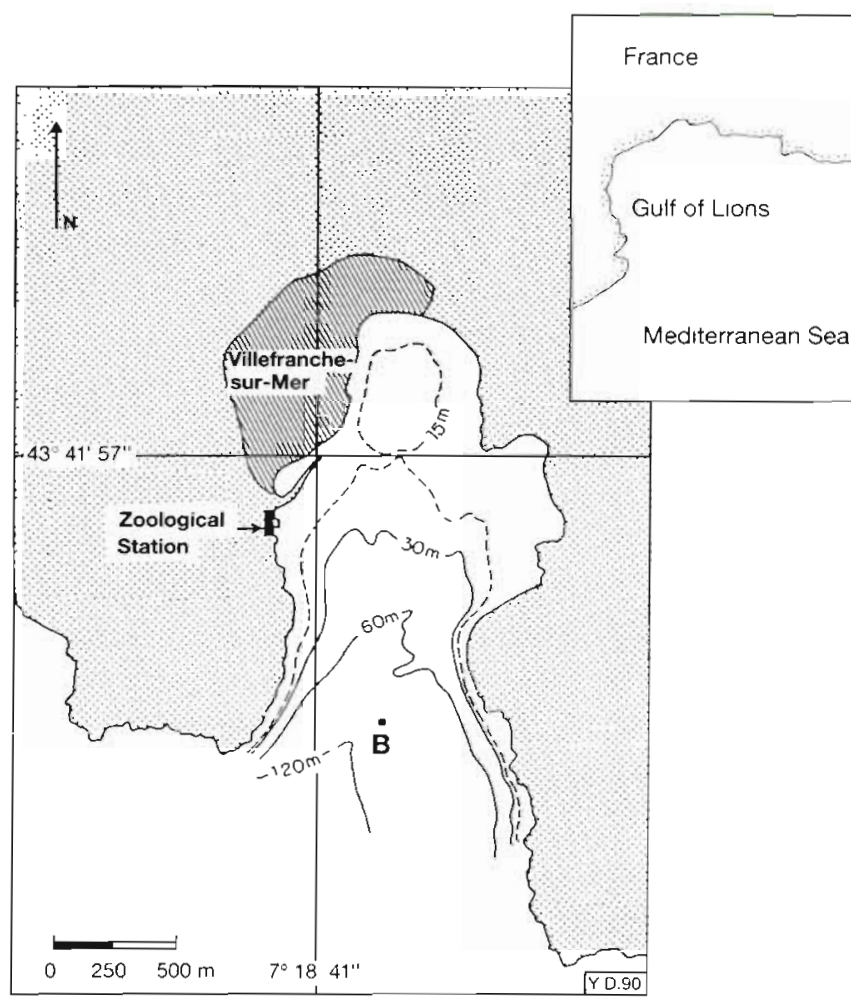

(1979) characterized oligotrophic versus eutrophic waters. Fowler et al. (1991) concluded that the Liguran Sea was eutrophic.

In oligotrophic waters, the picoplankton dominate both the blomass and the productivity (Platt \& LI 1986), as well as the ammonium uptake (e g. Probyn 1985, Probyn \& Lucas 1987, Glibert et al. 1988). On the other hand, the nanoplankton tend to be dominating in more eutrophic waters (e.g. Glibert et al. 1982a, Probyn 1987j. The ammonium uptake by picoplankton, however, is not necessarly accomplished solely by autotrophs, since heterotrophic bacteria have been demonstrated to exhıbit a substantial ammonıum assimulation (Wheeler \& Kurchman 1986). A large heterotrophic ammonium uptake, however, would impinge on the presumptions on which the concept of new and regenerated production is based (Probyn et al. 1990)

The microbial loop has been investigated for a long time in the Ligunan Sea, and especially in the Bay of Villefranche-sur-Mer (see map, Fig. 1). These waters are dominated by pico- and nanoplankton, mainly consisting of cyanobactena (Synechococcus sp.), heterotrophic bacteria and nanoflagellates (Rassoulzadegan 1979, Hagström et al. 1988, Lins da Silva 1991). Not even durng the spring bloom, however, does the abundance of microphytoplankton become very large. It is the autotrophic flagellates and the cyanobactena which are mostly responsible for the primary production (Hagstrom et al. 1988, Lins da Silva 1991,
Fig. 1. The NW Mediterranean Sea with an inset showing the Bay of Villefranchesur-Mer and the sampling station Point B

Wiadnyana 1991). Of the primary production $86 \%$ has been reported to be respired by heterotrophs, while only $6 \%$ is transferred to higher trophic levels (Hagström et al. 1988). Thus an active microbial loop and a high nutrient regeneration should be expected. This was indirectly demonstrated by Ferrier \& Rassoulzadegan (1991) inasmuch as the presence of heterotrophic protozoa enhanced the growth of picoand nanophytoplankton.

Since the NW Mediterranean Sea is characterized as oligotrophic and limited in nitrogen, and since the microbial loop has been shown to play an essential role in these waters, it was reasonable to ask the following questions: (1) How important is regenerated production compared to new production, (2) which organisms of the microbial loop are mainly responsible for regenerated production, and (3) how do these processes fluctuate over the year? In order to answer these questions, size-fractionated ${ }^{15} \mathrm{~N}$-enrichment experiments were undertaken, together with a thorough determination of the biological composition in the waters studied. To complement the determinations of new and regenerated production, studies of ammonuum regeneration were performed on some occasions.

\section{MATERIALS AND METHODS}

Experimental. Nitrogen uptake experiments were performed on the following dates: 9 and 30 November 1990; 12, 24 and 30 April; 15 and 31 May 1991. Ammonium regeneration studies were performed on 4 December 1990, 15 April, 17 and 30 May 1991.

Water was collected in the morning at $5 \mathrm{~m}$ depth at Point B in the Bay of Villefranche-sur-Mer, France (see map, Fig. 1) using a $30 \mathrm{l}$ Niskin sampler, and the expermental work was performed the same day as sampling. The water was size-fractionated using inverse filtration according to Sheldon \& Rassoulzadegan (1987), with $100 \mu \mathrm{m}$ filter mesh or 1 and $10 \mu \mathrm{m}$ Nuclepore filters $(\varnothing=142 \mathrm{~mm})$. For the uptake experments the water was post-fractionated, for the ammonium regeneration experiments it was pre- 
fractionated. Incubations were performed at $18^{\circ} \mathrm{C}$ and under constant artificial light conditions for all experiments. The duration of the incubations were between 4 and $5 \mathrm{~h}$.

In general, filtering of particulate material for chemical analysis (including ${ }^{15} \mathrm{~N}$-samples) was performed with pre-combusted $25 \mathrm{~mm}$ Whatman GF/F glass fibre filters (ashed at $450^{\circ} \mathrm{C}$ for 2 h). For all incubations and chemical analysis only acid-washed material was used $(2 \% \mathrm{HCl})$.

Biological composition. Triplicate samples were counted by epifluorescence microscopy according to Rassoulzadegan \& Sheldon (1986). Triplicate samples of $100 \mathrm{ml}$ for enumeration of ciliates and microphytoplankton were preserved with Lugol's solution and counted according to Utermöhl (1958).

Geometric cell volumes used for converting cell enumerations into biovolumes are given in Lins da Silva (1991). These cell volumes were originally obtained after several (>100) cell size measurements performed in the Bay of Villefranche-sur-Mer. The data will be presented as ppm by volume $\left(\mu \mathrm{m}^{3} \mathrm{ml}^{-1} \times 10^{6}\right)$. Biovolumes of the size intervals (i.e. $1-10 \mu \mathrm{m}, 10-100 \mu \mathrm{m}$ and $>100 \mu \mathrm{m}$ ) were also calculated for each experiment.

Nutrients, particulate material and chlorophyll a. Concentrations of ammonium and nitrate were measured on a Technicon Autoanalyzer II and an Alliance Instrument Evolution II, respectively, according to Tréguer \& Le Corre (1975). Ammonium was analyzed directly, while nitrate samples were stored frozen until analysis.

Samples for determination of particulate organic carbon and nitrogen were collected on glass fibre filters after fractionation, and subsequently dried and stored in an evacuated dessicator. For the experiments in 1990 the samples were analyzed on a W.C. Heraeus elemental analyzer (located at IAEA, Monaco), while the samples from 1991 were analyzed on a LECO 800 elemental analyzer (located at Centre d'Oceanologie, Marseille).

Concentrations of chlorophyll a (chl a) and phaeophytin a were measured during uptake experiments in spring 1991. Samples were collected on glass fibre filters after fractionation, stored frozen and subsequently analyzed according to Strickland \& Parsons (1972) using a Turner Fluorometer Model 10-005R. Calculations were performed according to Lorenzen (1966).

Nitrogen uptake and regeneration experiments. For the uptake experiments, the sampled seawater was divided into eight $10 \mathrm{l}$ glass bottles, to 4 of which were added $0.2 \mu \mathrm{mol} 1^{-1}$ of $98 \%{ }^{15} \mathrm{~N}$-ammonium, and to the other 4 were added $0.2 \mu \mathrm{mol} \mathrm{l} \mathrm{l}^{-1}$ of $98 \%{ }^{15} \mathrm{~N}$-nitrate. Ambient nutrient concentrations were analyzed prior to ${ }^{15} \mathrm{~N}$-additions. At the end of the incubation the water was fractionated, and 3 parallels of 1 to 21 from each bottle were collected on glass fibre filters, dried and stored in an evacuated desiccator until further analysis.

Ammonium regeneration rates were determined by using the ${ }^{15} \mathrm{~N}$-isotope dilution technique with subsequent extraction of indophenol (Selmer \& Sörensson 1986, Selmer 1988). The pre-fractionated seawater was divided into four $10 \mathrm{l}$ glass bottles and $0.2 \mu \mathrm{mol} \mathrm{l}^{-1}$ of $98 \%{ }^{15} \mathrm{~N}$-ammonium was added. In order to attain a sufficient amount of nitrogen for ${ }^{15} \mathrm{~N}$-analysis, $1 \mathrm{ml}$ of $1 \mathrm{mmol}{ }^{14} \mathrm{~N}-\mathrm{NH}_{4} \mathrm{Cl} \mathrm{l}^{-1}$ was added to the extraction samples $(240 \mathrm{ml})$ prior to the addition of reagents. Contamination blanks were also performed.

Analysis of atom $\%{ }^{15} \mathrm{~N}$ were performed with SOPRA GS1 emission spectrometer (ENSA-M/INRA, Montpellier) according to Kristiansen \& Paasche (1982). Uptake rates were calculated according to Dugdale \& Wilkerson (1986) and ammonium regeneration rates according to the Blackburn-Caperon model (Blackburn 1979, Caperon et al. 1979).

\section{RESULTS}

\section{Hydrography and nutrients}

In the Bay of Villefranche-sur-Mer, the seasonal variations in salinity are minor, and on the sampling occasions the salinity was always 38 psu (M.C. Corre $\& M$. Etienne pers. comm.). Irradiance at the time of sampling (Service Météorologique de l'Aéroport de Nice Côte d'Azur), together with the initial concentrations of ammonium and nitrate in the uptake studies (an average of the 4 incubation bottles) are presented in Table 1. Generally, both ammonium and nitrate

Table 1. Irradiance $\left(\mathrm{J} \mathrm{cm}^{-2}\right)$ at the time of sampling. Initial nutrient concentrations ( $\mu \mathrm{mol} \mathrm{l}^{-1}$ ) in uptake experiments, taken as a mean value of the 4 incubation bottles and with the standard deviations (SD) shown

\begin{tabular}{|cccccc|}
\hline \multirow{2}{*}{ Date } & Irradiance & \multicolumn{3}{c}{ Ammonium } \\
Mean value & SD & $\begin{array}{c}\text { Nitrate } \\
\text { Mean value }\end{array}$ & SD \\
\hline 1990 & & & & & \\
$9 \mathrm{Nov}$ & 1082 & 0.27 & 0.07 & & \\
$30 \mathrm{Nov}$ & 840 & 0.17 & 0.04 & 0.17 & 0.07 \\
$4 \mathrm{Dec}$ & 547 & & & & \\
1991 & & & & & \\
$12 \mathrm{Apr}$ & 2155 & 0.06 & 0.00 & 0.03 & 0.02 \\
$15 \mathrm{Apr}$ & 1956 & & & & \\
$24 \mathrm{Apr}$ & 1373 & 0.08 & 0.01 & 0.05 & 0.03 \\
$30 \mathrm{Apr}$ & 1992 & 0.09 & 0.00 & 0.04 & 0.03 \\
$15 \mathrm{May}$ & 1854 & 0.11 & 0.00 & 0.94 & 0.28 \\
$17 \mathrm{May}$ & 2882 & & & & \\
$30 \mathrm{May}$ & 1485 & & & & \\
$31 \mathrm{May}$ & 2822 & 0.10 & 0.00 & 0.00 & 0.00 \\
\hline
\end{tabular}


Table 2. Contribution (\%) of the different groups to total biovolume on each sampling date

\begin{tabular}{|c|c|c|c|c|c|c|c|c|c|c|c|}
\hline Groups & $\begin{array}{l}1990 \\
9 \text { Nov }\end{array}$ & $30 \mathrm{Nov}$ & $4 \mathrm{Dec}$ & $\begin{array}{l}1991 \\
12 \mathrm{Apr}\end{array}$ & $15 \mathrm{Apr}$ & $24 \mathrm{Apr}$ & $30 \mathrm{Apr}$ & 15 May & 17 May & 30 May & 31. May \\
\hline \multicolumn{12}{|l|}{ Fraction $<1 \mu \mathrm{m}$} \\
\hline Cyanobacteria & 11.54 & 5.56 & 2.49 & 15.99 & 15.49 & 6.30 & 5.22 & 3.71 & 8.93 & 6.21 & 7.72 \\
\hline Prochlorophyte & 0.01 & 0.02 & 0.01 & 0.01 & 0.05 & 0.03 & 0.04 & 0.01 & 0.08 & 0.02 & 0.01 \\
\hline Autotrophic picoflagellates & 0.60 & 0.52 & 1.79 & 1.13 & 0.30 & 0.56 & 1.15 & 0.83 & 2.70 & 1.39 & 1.62 \\
\hline Autotrophic nanoflagellates & 6.95 & 5.95 & 7.55 & 9.12 & 1.45 & 6.85 & 10.81 & 4.79 & 7.15 & 4.59 & 6.51 \\
\hline Microphytoplankton & 0.00 & 0.00 & 0.00 & 0.00 & 0.00 & 0.00 & 0.00 & 0.00 & 0.00 & 0.00 & 0.00 \\
\hline Bacteria & 70.81 & 84.25 & 77.09 & 62.21 & 77.13 & 77.33 & 75.15 & 76.79 & 60.08 & 79.47 & 73.11 \\
\hline Heterotrophic picoflagellates & 0.36 & 0.87 & 1.08 & 1.30 & 1.90 & 1.29 & 1.35 & 1.04 & 1.93 & 1.79 & 1.16 \\
\hline Heterotrophic nanoflagellates & 9.70 & 2.82 & 9.98 & 10.23 & 3.71 & 7.58 & 6.26 & 12.81 & 19.11 & 6.52 & 9.85 \\
\hline Ciliates & 0.00 & 0.00 & 0.00 & 0.00 & 0.00 & 0.00 & 0.00 & 0.00 & 0.00 & 0.00 & 0.00 \\
\hline \multicolumn{12}{|l|}{ Fraction $<10 \mu \mathrm{m}$} \\
\hline Cyanobacteria & 7.60 & 4.51 & 3.35 & 8.47 & 10.02 & 6.53 & 3.42 & 3.41 & 7.76 & 3.08 & 4.15 \\
\hline Prochlorophyte & 0.01 & 0.01 & 0.01 & 0.01 & 0.01 & 0.02 & 0.02 & 0.02 & 0.02 & 0.01 & 0.01 \\
\hline Autotrophic picoflacgellates & 0.05 & 0.74 & 0.75 & 0.89 & 0.89 & 0.46 & 0.63 & 0.99 & 1.16 & 0.72 & 0.66 \\
\hline Autotrophic nanoflagellates & 36.15 & 36.15 & 26.16 & 45.39 & 39.64 & 21.87 & 41.49 & 48.00 & 50.32 & 48.62 & 39.24 \\
\hline Microphytoplankton & 7.04 & 3.79 & 7.76 & 0.74 & 1.54 & 1.59 & 5.17 & 5.72 & 1.00 & 5.83 & 7.61 \\
\hline Bactena & 35.39 & 42.40 & 45.80 & 30.07 & 2.52 & 59.95 & 33.85 & 23.33 & 30.22 & 20.34 & 35.18 \\
\hline Heterotrophic picoflagellates & 0.29 & 0.62 & 0.60 & 0.62 & 1.21 & 0.50 & 0.71 & 0.06 & 0.56 & 0.70 & 0.43 \\
\hline Heterotrophic nanoflagellates & 6.12 & 8.06 & 8.63 & 12.66 & 12.55 & 10.40 & 8.76 & 11.62 & 7.65 & 15.12 & 5.08 \\
\hline Ciliates & 0.70 & 0.21 & 0.52 & 0.29 & 0.12 & 0.15 & 1.24 & 0.63 & 0.30 & 0.25 & 1.02 \\
\hline \multicolumn{12}{|l|}{ Fraction $<100 \mu \mathrm{m}$} \\
\hline Cyanobacteria & 7.03 & 8.82 & 30.19 & 7.15 & 7.82 & 5.83 & 3.32 & 2.90 & 3.89 & 2.15 & 1.81 \\
\hline Prochlorophyte & 0.01 & 0.01 & 0.01 & 0.01 & 0.01 & 0.02 & 0.01 & 0.01 & 0.01 & 1.00 & 0.01 \\
\hline Autotrophic picoflagellates & 0.48 & 0.75 & 0.55 & 0.64 & 0.66 & 0.56 & 0.49 & 0.45 & 1.00 & 0.42 & 0.25 \\
\hline Autotrophic nanoflagellates & 28.99 & 21.81 & 24.57 & 44.71 & 38.49 & 28.37 & 39.98 & 25.42 & 38.58 & 28.78 & 23.01 \\
\hline Microphytoplankton & 7.30 & 7.87 & 9.58 & 2.56 & 5.31 & 7.20 & 5.68 & 20.44 & 13.84 & 20.16 & 28.41 \\
\hline Bacteria & 34.13 & 39.61 & 41.27 & 26.19 & 26.66 & 36.70 & 31.95 & 21.12 & 23.48 & 20.72 & 18.63 \\
\hline Heterotrophic picoflagellates & 0.34 & 0.46 & 0.69 & 0.64 & 0.76 & 0.57 & 0.66 & 0.77 & 0.43 & 0.59 & 0.41 \\
\hline Heterotrophic nanoflagellates & 12.98 & 16.34 & 9.96 & 14.67 & 12.63 & 12.25 & 9.82 & 11.28 & 6.64 & 11.03 & 8.84 \\
\hline Ciliates & 2.50 & 2.97 & 2.60 & 0.96 & 2.84 & 2.37 & 2.97 & 3.68 & 1.07 & 2.14 & 1.66 \\
\hline \multicolumn{12}{|l|}{ Uniractionated water } \\
\hline Cyanobacteria & 6.56 & 2.69 & 2.78 & 7.08 & 7.73 & 7.65 & 2.64 & 2.17 & 2.25 & 2.08 & 1.19 \\
\hline Prochlorophyte & 0.01 & 0.01 & 0.01 & 0.01 & 0.01 & 0.01 & 0.01 & 0.01 & 0.01 & 0.01 & 0.01 \\
\hline Autotrophic picoflagellates & 0.54 & 0.45 & 0.49 & 0.65 & 0.58 & 0.58 & 0.47 & 0.50 & 0.61 & 0.46 & 0.19 \\
\hline Autotrophic nanoflagellates & 31.33 & 18.50 & 21.35 & 35.24 & 42.86 & 42.64 & 35.35 & 26.19 & 26.61 & 27.63 & 14.77 \\
\hline Microphytoplankton & 8.50 & 14.42 & 11.87 & 4.81 & 5.17 & 5.46 & 10.43 & 23.17 & 22.48 & 19.25 & 38.83 \\
\hline Bacteria & 28.57 & 33.62 & 40.43 & 25.40 & 26.92 & 26.91 & 29.95 & 18.73 & 22.81 & 19.72 & 15.87 \\
\hline Heterotrophic picoflagellates & 0.38 & 0.41 & 0.47 & 0.47 & 0.01 & 0.58 & 0.70 & 0.71 & 0.15 & 0.34 & 0.10 \\
\hline Heterotrophic nanoflagellates & 14.18 & 16.47 & 10.77 & 19.53 & 0.01 & 9.71 & 9.78 & 11.64 & 3.48 & 8.84 & 2.75 \\
\hline Ciliates & 2.77 & 3.52 & 3.04 & 2.44 & 0.01 & 1.43 & 2.10 & 1.67 & 6.65 & 8.31 & 6.73 \\
\hline
\end{tabular}

concentrations were higher in autumn than in spring. A sharp increase in nitrate concentrations, however, was observed on 15 May. This was probably due to a preceding rainfall, and 2 wk later the nitrate concentrations had returned to the previous low (and for the season normal) concentrations.

\section{Biological composition}

The contributions of the different groups of organisms in percentage of the total biovolume are given in Table 2. Biovolumes of the size intervals (i.e. 1-10 $\mu \mathrm{m}, 10-100 \mu \mathrm{m}$ and $>100 \mu \mathrm{m}$ ) are presented in Fig. 2. Hereafter, the following abbreviations will be used for the various groups of flagellates: APF, autotrophic picoflagellates; HPF, heterotrophic picoflagellates; ANF, autotrophic nanoflagellates; HNF, heterotrophic nanoflagellates. The coefficients of variance (calculated for ppm) were as follows: Prochlorophytes 1 to $3 \%$, cyanobacteria 0.5 to $3 \%$, APF 1 to $4 \%$, ANF 1 . to $10 \%$, microphytoplankton 3 to $20 \%$, heterotrophic bacteria 3 to $10 \%$, HPF 1 to $4 \%$, HNF 1 to $6 \%$ and ciliates 0.2 to $1 \%$.

The $<10 \mu \mathrm{m}$ fractions were mostly dominated by heterotrophic bacteria, cyanobacteria and ANF. Heterotrophic bacteria represented ca 70 and $30 \%$ of the total biovolume in the $<1$ and $<10 \mu \mathrm{m}$ fractions, 

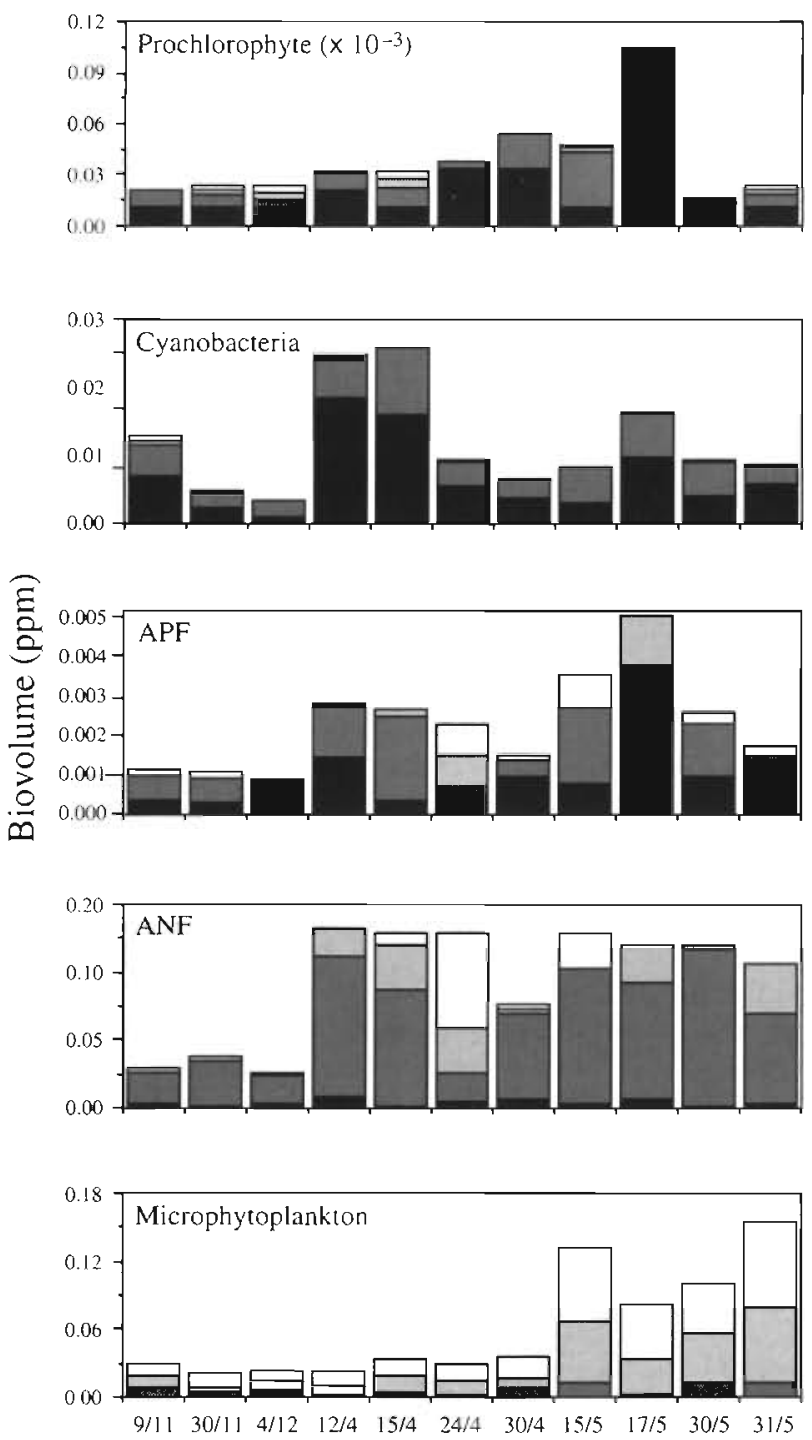

Date

respectively. They were abundant in all experiments, exhibiting a mean biovolume of ca $0.10 \mathrm{ppm}$ (except for $0.06 \mathrm{ppm}$ in Nov/Dec). On average, cyanobacteria accounted for 50 and $12 \%$ of the autotrophs in the $<1 \mu \mathrm{m}$ and $<10 \mu \mathrm{m}$ fractions respectively, while ANF accounted for 43 and $79 \%$ respectively. Cyanobacteria were particularly abundant in the first $2 \mathrm{wk}$ of April (0.03 ppm), but had a lower biovolume in the other experiments (0.01 to $0.02 \mathrm{ppm})$. ANF exhibited lower biovolume in Nov/Dec (0.03 ppm) than in April/May $(0.15$ to $0.20 \mathrm{ppm})$. In these 2 fractions, picoflagellates and prochlorophytes exhibited 10 to 100 times lower biovolume than the other groups. Dinoflagellates dominated the microphytoplankton in the $<10 \mu \mathrm{m}$ fraction.

In the $<100 \mu \mathrm{m}$ fraction, the biovolumes of heterotrophic bacteria, cyanobacteria and ANF were nearly
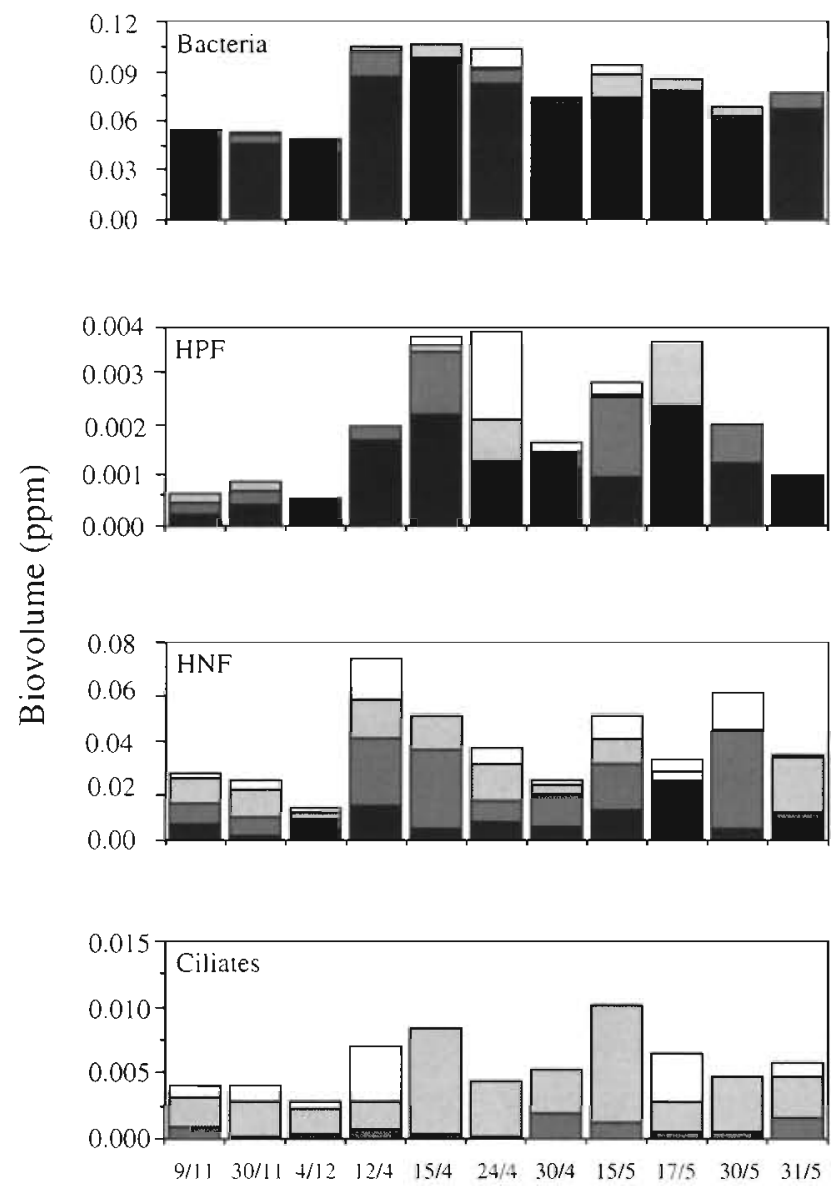

Date

$<1 \mu \mathrm{m}$ $1-10 \mu \mathrm{m}$

$10-100 \mu \mathrm{m}$

$>100 \mu \mathrm{m}$

Fig. 2. Biovolume of plankton ( $\mathrm{ppm}$ ) in size intervals for both uptake and regeneration experiments. In this and subsequent figures, dates are given in the form day/month

the same as in the $<10 \mu \mathrm{m}$ fraction, while the HNF and the microphytoplankton were more abundant. The microphytoplankton were mostly dominated by dinoflagellates throughout the year and especially by Ceratium sp. in spring. Microphytoplankton biovolume remained low from November to April $(0.03 \mathrm{ppm})$, but increased suddenly in May during the spring bloom and reached values of 0.12 to $0.16 \mathrm{ppm}$. In the last experiment, a bloom of the diatom Rhizosolenia styliformis was observed. At this time increases in abundances of Chaetoceros sp. and Leptocylindricus styliformis also occured. Ciliates were also abundant in these fractions with a mean biovolume of ca 0.05 to $0.10 \mathrm{ppm}$. The unfractionated water was mostly identical to the $<100 \mu \mathrm{m}$ fraction, except for a slight increase in microphytoplankton and ciliate biovolume. 


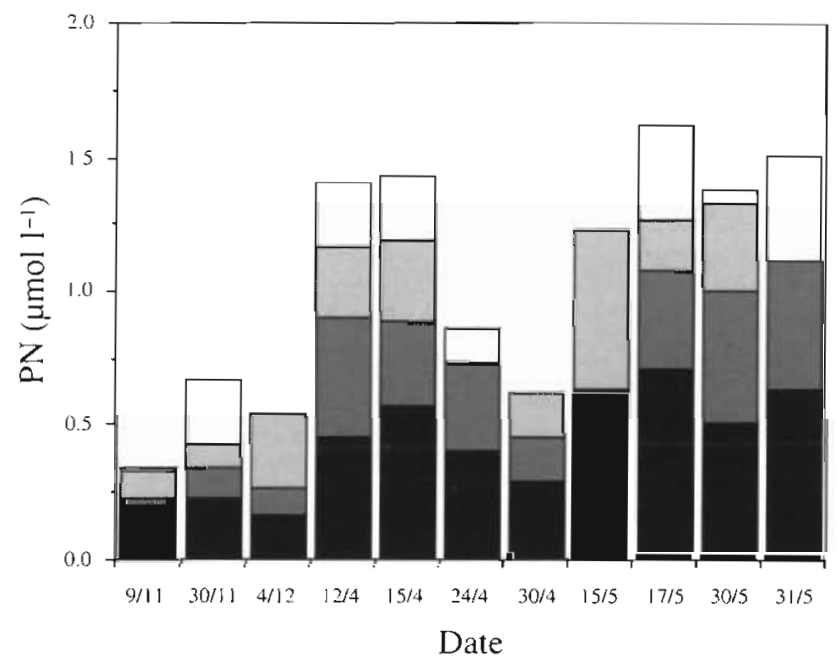

Fig. 3. Particulate organic nitrogen concentrations $\left(\mu \mathrm{mol} 1^{-1}\right)$ in size intervals for both uptake and regeneration experiments (legend as in Fig. 2)

\section{Particulate organic material, chlorophyll a and phaeophytin a}

Concentrations of particulate organic nitrogen (PN) in the different size intervals for all the experiments are shown in Fig. 3. The $C: N$ atomic ratios of inclusive size classes are shown in Fig. 4. In general, the concentrations of $P N$ and particulate organic carbon (PC) follow the same pattern as biovolumes. The $<1 \mu \mathrm{m}$ fraction contributed ca 20 to $40 \%$ to the total PN and PC. This high contribution of the smaller organisms to particulate material is also seen inasmuch as PC and PN were positively correlated with cyanobacteria, heterotrophic bacteria and HPF $(p=0.001)$, and also with prochlorophytes and APF $(p=0.01)$, but not with nanoflagellates and microphytoplankton.

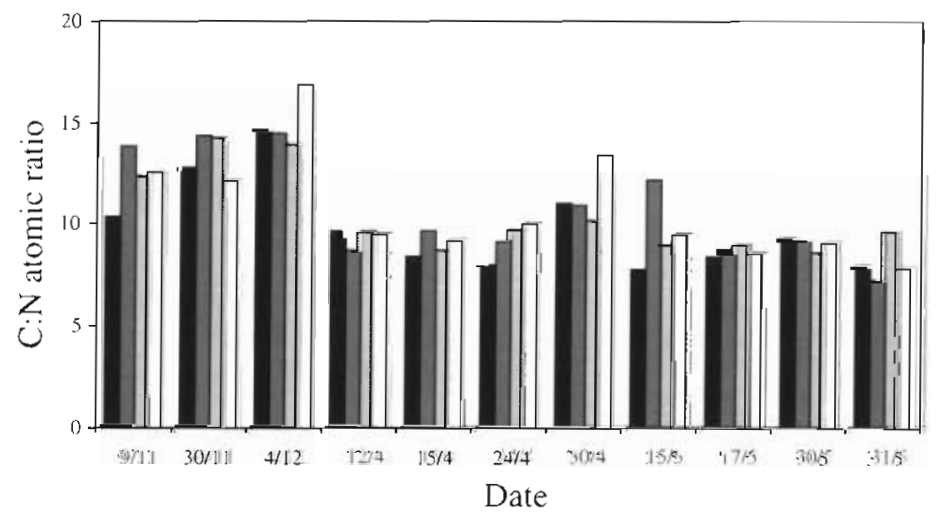

$<1 \mu \mathrm{m} \square<10 \mu \mathrm{m} \square<100 \mu \mathrm{m} \quad \square$ unfractionated water

Fig. 4. C:N atomic ratios in inclusive size classes

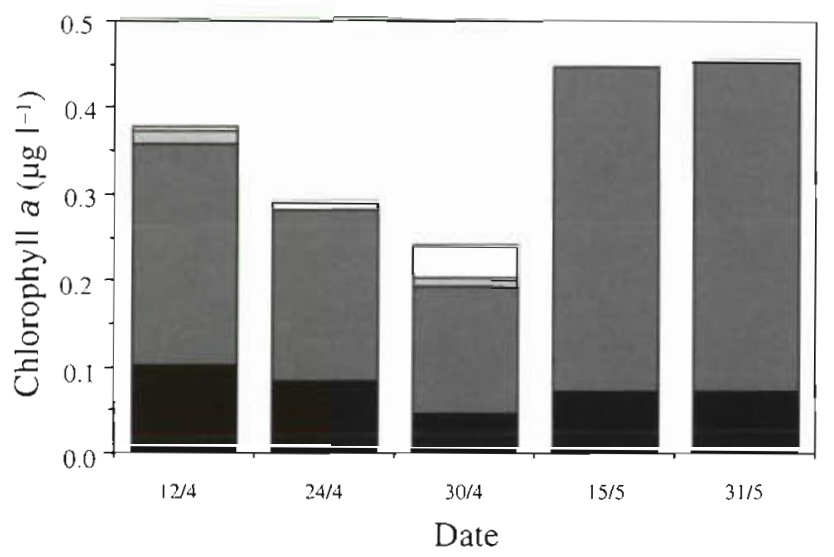

Fig. 5. Chlorophyll a concentration $\left(\mu \mathrm{g} \mathrm{l}^{-1}\right)$ in size intervals from uptake experiments during spring 1992 (legend as in Fig. 2)

Concentrations of chl a decreased during early spring up to 30 April, after which the concentrations increased again (Fig. 5). There was a clear predominance of the 1-10 $\mu \mathrm{m}$ size interval in the distribution of chl a concentrations. Chl a was significantly correlated only with ANF ( $\mathrm{p}=0.001)$, the major autotrophic constituent of the $1-10 \mu \mathrm{m}$ size interval. Phaeophytin a concentrations were approx. $0.10 \mu \mathrm{g} \mathrm{l}^{-1}$ up to $30 \mathrm{April}$, and increased later to $0.15 \mu \mathrm{g} \mathrm{l}^{-1}$. Compared to $\mathrm{chl} a$, there was a shift in predominance towards the $10-100 \mu \mathrm{m}$ size interval, except for $30 \mathrm{April}$ when the $1-10 \mu \mathrm{m}$ size interval dominated.

\section{Uptake of nitrogenous nutrients}

The ammonium uptake rates of the different size intervals and as a percentage of the total uptake (i.e. of the unfractionated water) are shown in Figs. 6 \& 7 , respectively. In general, the ammonium uptake rates increased during the year (from autumn to spring), and exhibited the same seasonal pattern as observed for organic material and biovolume

In autumn, the 1-10 $\mu \mathrm{m}$ size interval dominated the ammonium uptake $\left(0.7\right.$ to $\left.0.9 \mathrm{nmol} \mathrm{l}^{-1} \mathrm{~h}^{-1}\right)$, followed by the $<1 \mu \mathrm{m}$ fraction $\left(0.4\right.$ to $0.7 \mathrm{nmol} \mathrm{l}^{-1}$ $\mathrm{h}^{-1}$ ). In spring, however, the $<1 \mu \mathrm{m}$ fraction dominated $\left(0.7\right.$ to $\left.3.4 \mathrm{nmol} \mathrm{I}^{-1} \mathrm{~h}^{-1}\right)$, followed by the $1-10 \mu \mathrm{m}$ size interval $\left(0.7\right.$ to $\left.3.2 \mathrm{nmol} \mathrm{l}^{-1} \mathrm{~h}^{-1}\right)$, while the fractions $>10 \mu \mathrm{m}$ generally exhibited lower uptake rates (except for 15 and 31 May). Generally, the importance of the $<1 \mu \mathrm{m}$ fraction increased during early spring up to 30 April (comprising 69\%; Fig. 7), simultaneously with a decrease in the total uptake rates (from 5.1 to $1.3 \mathrm{nmol}^{-1} \mathrm{~h}^{-1}$; Fig 6). After 30 April, the total uptake increased (to $8.7 \mathrm{nmol} \mathrm{l}^{-1} \mathrm{~h}^{-1}$ ) with a predominance of the size intervals $>1 \mu \mathrm{m}$. 


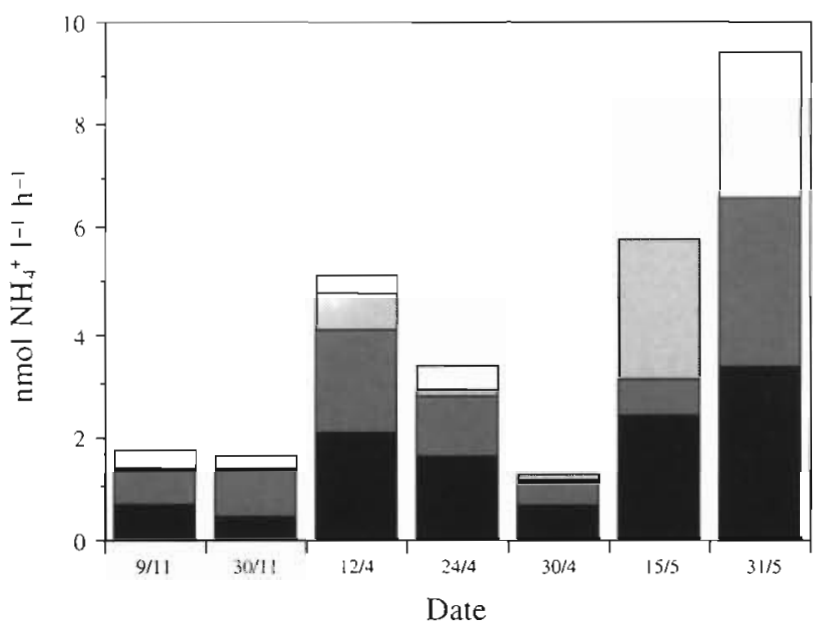

Fig. 6. Rates of ammonium uptake (nmol $\mathrm{l}^{-1} \mathrm{~h}^{-1}$ ) in size intervals (legend as in Fig. 2)

Since there was a clear shift in the observed parameters (ammonium uptake, organic material and biovolume) up to and after 30 April, the data were divided into 2 parts for the statistical treatments. $\mathrm{R}^{2}$ values and associated probabilities (p) are summarized in Table 3. Up to 30 April ammonium uptake was significantly correlated with $P N$, $\mathrm{PC}$ and all groups of organisms except the microphytoplankton, but not with chl a, After 30 April a significant correlation was observed with chl a, PN, $\mathrm{PC}$ and also with microphytoplankton and cyanobacteria.

Compared to the ammonium uptake rates, the nitrate uptake was generally low or non-existent (Fig. 8). The highest rates were observed in autumn, and mostly within the $<1 \mu \mathrm{m}$ fraction $\left(0.6 \mathrm{nmol} \mathrm{l}^{-1} \mathrm{~h}^{-1}\right)$. Elevated rates were also observed on 24 April $\left(0.2 \mathrm{nmol} \mathrm{l}^{-1} \mathrm{~h}^{-1}\right.$ in the dominating $10-100 \mu \mathrm{m}$ size interval) and on 31 May $\left(0.3 \mathrm{nmol} \mathrm{l}^{-1} \mathrm{~h}^{-1}\right.$ in the $1-10 \mu \mathrm{m}$ size interval). There was no significant correlation between nitrate uptake and biovolume.

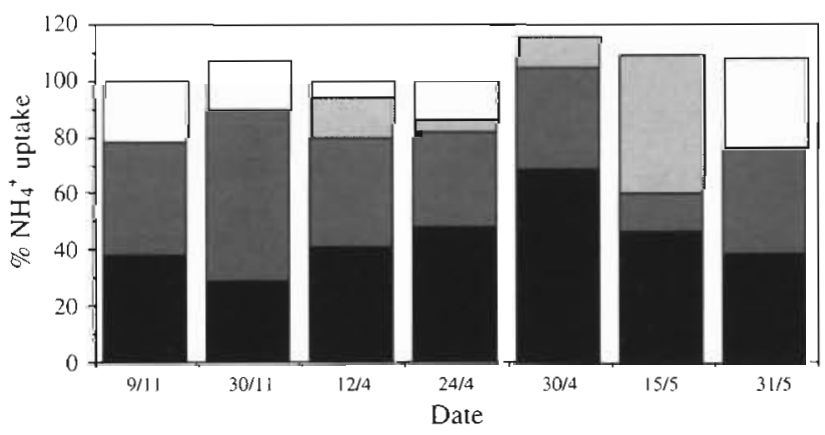

Fig. 7. Rates of ammonium uptake as percentage of the total uptake (unfractionated samples) (legend as in Fig. 2)
Table 3. $R^{2}$ values (coefficient of determination) from the significant linear regressions between ammonium uptake rates (nmol $\mathrm{l}^{-1} \mathrm{~h}^{-1}$ ) and the different groups of organisms (ppm) or particulate carbon and nitrogen $\left(\mu \mathrm{mol} 1^{-1}\right)$ or chlorophyll

$\left(\mu \mathrm{g} \mathrm{l}^{-1}\right)$. The parameter $\mathrm{p}$ is the associated probability

\begin{tabular}{|lcc|}
\hline Groups & \multicolumn{2}{c|}{ Ammonium uptake rates } \\
& Up to 30 April & After 30 April \\
\hline Cyanobacteria & $0.77(p=0.0001)$ & $0.47(p=0.013)$ \\
Prochlorophytes & $0.40(p=0.0180)$ & No correlation \\
APF & $0.83(p=0.0001)$ & No correlation \\
ANF & $0.76(p=0.0001)$ & No correlation \\
Microphytoplankton & No correlation & $0.74(p=0.003)$ \\
Bacteria & $0.78(p=0.0030)$ & No correlation \\
HPF & $0.74(p=0.0001)$ & No correlation \\
HNF & $0.84(p=0.0001)$ & No correlation \\
Particulate nitrogen & $0.86(p=0.0001)$ & $0.92(p=0.0001)$ \\
Particulate carbon & $0.72(p=0.0001)$ & $0.70(p=0.0007)$ \\
Chlorophyll $a$ & No correlation & $0.45(p=0.0164)$ \\
& & \\
\hline
\end{tabular}

\section{Ammonium regeneration}

The rates of ammonium regeneration are shown in Fig. 9. The rates are presented as inclusive size classes, since the incubations were pre-fractionated and thus each incubation bottle (and size-fraction) represented different ecosystems. Provided it is possible, however, we try in the text to discuss the results in terms of size intervals.

Organisms $>10 \mu \mathrm{m}$ exhibited relatively high rates of ammonium regeneration on 4 December (15 and $36 \mathrm{nmol} \mathrm{l}^{-1} \mathrm{~h}^{-1}$ in the $<100 \mu \mathrm{m}$ fraction and unfractionated water, respectively, and thus the regeneration activity was rather equally dispersed between the size

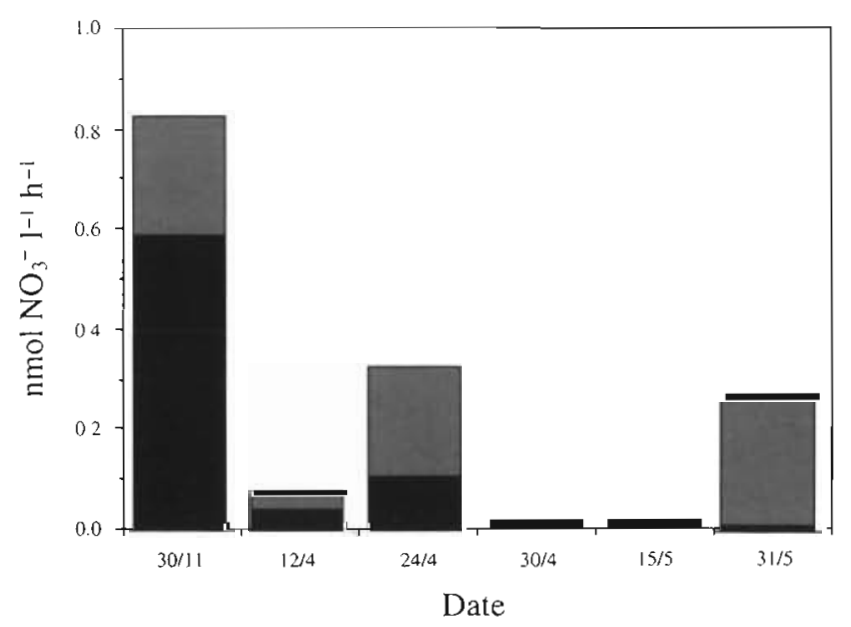

Fig. 8. Rates of nitrate $\left(\mathrm{nmol} \mathrm{l}^{-1} \mathrm{~h}^{-1}\right)$ in size intervals (legend as in Fig. 2) 


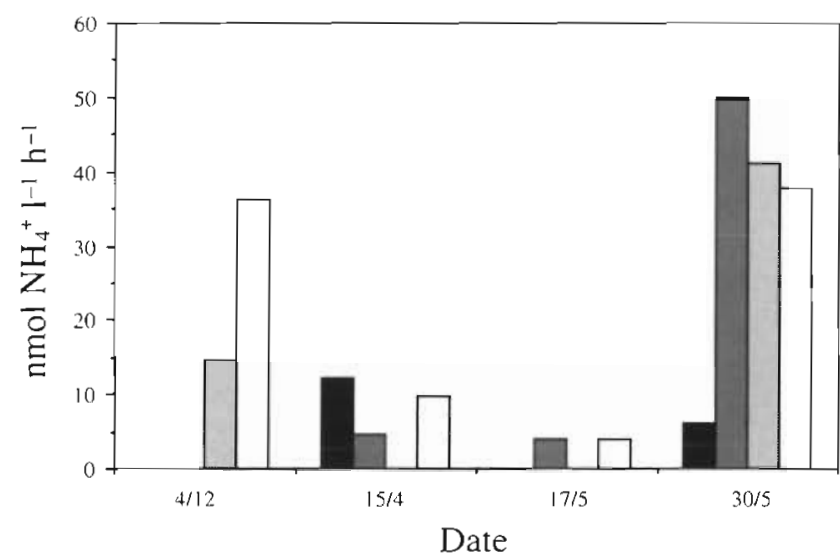

Fig. 9. Rates of ammonium regeneration $\left(\mathrm{nmol} \mathrm{l}^{-1} \mathrm{~h}^{-1}\right.$ ) in inclusive size classes (legend as in Fig. 4)

intervals $10-100 \mu \mathrm{m}$ and $>100 \mu \mathrm{m}$ ). On 30 May the organisms in the size interval $1-10 \mu \mathrm{m}$ exhibited the highest ammonium regeneration rates encountered during these studies (up to $50 \mathrm{nmol} \mathrm{l}^{-1} \mathrm{~h}^{-1}$ ). Contrary to this pattern the $<1 \mu \mathrm{m}$ fraction dominated on 15 April (12 nmol $\mathrm{l}^{-1} \mathrm{~h}^{-1}$ ), while on 17 May organisms $>1 \mu \mathrm{m}$ dominated with generally very low rates $\left(<5 \mathrm{nmol} \mathrm{l} \mathrm{l}^{-1} \mathrm{~h}^{-1}\right)$.

\section{DISCUSSION}

\section{Seasonal variations}

From the results presented above, it was possible to discern 3 periods in relation to the biological composition and ammonium uptake rates: Nov/Dec, April (up to 30 April) and May (after 30 April). Since the experimental work was not equally distributed over the year, this division into periods could be somewhat artificial. To facilitate the discussion, however, we use the denominations autumn (Nov/Dec), April and May. The incubation conditions were held constant during all experiments, and this could have imposed an artifact. However, since the seasonal variations we observed in biological composition were reflected in the nitrogen dynamics, we believe this artifact to be of minor importance.

\section{Biological composition}

In the Bay of Villefranche-sur-Mer, the waters are considered to be coastal temperate, and productivity is also closely related to seasons, with highest productivity during spring when the microphytoplankton bloom appears. Microphytoplankton, however, are not as important here as in some other temperate waters, where diatoms are responsible for the major primary production during spring bloom (e.g. Smetacek 1981, Takahashi \& Bienfang 1983, Holligan et al. 1984, Joint et al. 1986). In the Ligurian Sea, the spring bloom is usually due to increases of Chaetoceros sp., Leptocylindricus sp. and Rhizosolenia sp. (Wiadnyana 1991).

The biovolumes observed in the present work are in the same order of magnitude as those observed earlier at Point B (Lins da Silva 1991, Wiadnyana 1991). The pico- and nanoplankton dominated the plankton composition at Point B. They accounted for $70 \%$ of the total organic particulate carbon, values comparable to those obtained by Pomeroy (1974), Sherr et al. (1986), Andersen (1988) and Rassoulzadegan (1990). Heterotrophic bacteria was the most important group. Mean concentrations of oligotrichous ciliates 11 to 2 cells $\mathrm{ml}^{-1}$ ) were within the range of concentrations measured earlier in these waters (Rassoulzadegan \& Gostan 1976, Rassoulzadegan 1977).

Sometimes, however, there were inconsistencies in the cell numbers relative to the filter sizes. The bacterial cell numbers could increase in the 10-100 $\mu \mathrm{m}$ size interval as compared with the 1-10 $\mu \mathrm{m}$ size interval. This was probably due to a smaller percentage of bacteria destroyed by filtration on $100 \mu \mathrm{m}$ filter mesh than on $10 \mu \mathrm{m}$ Nuclepore filters. It could also have been caused by bacteria attached to detritus, but this was not observed in the microscope. Another inconsistency was the presence of ANF in the $<1 \mu \mathrm{m}$ fraction. An exact separation of plankton into size classes using filtration has, however, been proven difficult (Li 1990, Stockner et al. 1990).

Prochlorophytes, autotrophic picoplankton which recently have received much attention, were originally observed only in the lower part of the photic zone near the nitracline in the Atlantic and therefore presumed to utilize new nutrients (Chisholm et al. 1988, Neveux et al. 1989). Later, prochlorophytes were observed in the entire photic zone in the Mediterranean Sea (Vaulot et al. 1990). In this study, prochlorophytes were counted with epifluorescent microscopy, which could have resulted in an underestimation of cell numbers due to bleaching under the light source. In general, we found 10 times lower abundances than Vaulot et al. (1990). In our studies, prochlorophytes were always present at $5 \mathrm{~m}$ and seemed to prefer new nutrients (inasmuch as ammonium uptake was less significantly correlated with prochlorophytes than with the other autotrophic plankton). Prochlorophytes have been shown to react rapidly to nitrogen pulses (Vaulot \& Partensky 1992). This was clearly evident on $17 \mathrm{May}$, when the elevated nitrate concentrations had caused enhanced growth of the prochlorophytes. 


\section{Nitrogen uptake}

Ammonium dominated the nitrogen uptake with up to $100 \%$ in April and May. The ammonium uptake was generally dominated by pico-and nanoplankton in the size fractions $<10 \mu \mathrm{m}$. These were especially cyanobacteria and ANF, but also heterotrophic bacteria (Figs $6 \& 7$, Table 3). Of the autotrophs, cyanobacteria generally constituted the largest part in the $<1 \mu \mathrm{m}$ fraction, while ANF dominated the $1-10 \mu \mathrm{m}$ size interval (Table 2, Fig. 2). Even if the biovolumes of APF were low, their significant correlation with ammonium uptake implies an important contribution to the ammonium uptake. According to the statistical treatments, the heterotrophic bacteria contributed less to ammonium uptake than the autotrophs (Table 3). Presumably, heterotrophic bacteria will assimilate rather than regenerate ammonium when the organic substrate is nitrogen limited (Goldman et al. 1987, Goldman \& Dennett 1991). Although dissolved organic material was not measured in the present work, the high particulate $\mathrm{C}: \mathrm{N}$ ratios observed (Fig. 4) support a preferential bacterial ammonium assimilation. Also, bacterial ammonium uptake have been demonstrated to be substantial amongst picoplankton (Wheeler \& Kirchman 1986)

It was only in May that ammonium uptake was observed to any extent in the larger size intervals consisting of microphytoplankton (Figs. $6 \& 7$ ). The statistical treatments showed obtained a good correlation only between uptake rates and microphytoplankton and to a lesser degree cyanobacteria. Ammonium uptake was also more significantly correlated with microphytoplankton than with chl a, probably due to the diatoms and dinoflagellates present (see 'Results'), all of which have low chl a concentrations relative to other pigments (Sournia 1986, Ricard 1987).

The uptake rates of nitrate were always much lower than those of ammonium. The dependance of microphytoplankton on nitrate has previously been indirectly demonstrated in the same area by Ferrier \& Rassoulzadegan (1991). In spite of the expected interdependance, neither the peak in nitrate uptake on 30 November nor that on 24 April coincided with any increased microphytoplankton biovolumes (Figs. 2 \& 8). The spring bloom, with an increased abundance of microphytoplankton, appeared in May. Although elevated nitrate concentrations were observed in situ on 15 May, the measured nitrate uptake rates were almost zero. From 15 to 17 May there occured an increase in biovolume of most of the plankton $<1 \mu \mathrm{m}$. There are no uptake measurements from 17 May, but presumably the enhanced irradiance (see Table 1) contributed to an increased primary production. Elevated uptake rates of both nitrate and ammonium were observed on 31 May (Figs. 6 \& 8). A similar delayed response to elevated nitrate concentrations was reported from the same area by Martin et al. (1989). They found a relationship between heavy rainfall, a rapid increase in surface water nitrate concentrations and a subsequent increase in chl a in less than $1 \mathrm{wk}$.

Our findings are consistent with the nitrogen uptake studies performed in the Gulf of Lions, where the $<5 \mu \mathrm{m}$ size class contributed $67 \%$ to the nitrogen uptake in winter, and over $80 \%$ to the primary production in both summer and winter (Owens et al. 1989, Woodward et al. 1990). Although the Gulf of Lions is strongly influenced by the fresh-water discharge and nutrient loading from the Rhone River, the quoted results were from the boundary area between fresh-water and sea-water which is limited in nitrogen (Woodward \& Owens 1989), and which exhibits cell densities typical of the Mediterranean Sea open sea areas (Cruzado \& Velásques 1989), and therefore should be comparable to the Ligurian Sea. Owens et al. (1989) reported depthintegrated nitrogen uptake of $0.58 \mathrm{nmol} \mathrm{NO}_{3}^{-} \mathrm{l}^{-1} \mathrm{~h}^{-1}$ and $1.46 \mathrm{nmol} \mathrm{NH}_{4}{ }^{+} \mathrm{l}^{-1} \mathrm{~h}^{-1}$ during winter, which is only comparable with our results from autumn. The generally low ammonium uptake rates we observed, however, are comparable to, or lower than, observations from oligotrophic regions (e.g. Wheeler \& Kirchman 1986, Probyn \& Lucas 1987, Glibert et al. 1988, Harrison \& Wood 1988). The uptake rates could have been enhanced by the addition of $0.2 \mu \mathrm{mol} \mathrm{N}^{-1}$, due to the enrichment effect and/or a surge uptake. However, due to the low uptake rates observed, we do not believe this to be a major error. On the other hand, our results could have been underestimated since we did not correct for isotope dilution (Glibert et al. 1982b). Such a correction, however, would only have resulted in an even higher dominance of regenerated production. Therefore, the general conclusion that this ecosystem is dominated to a very large extent by regenerated production would not be altered.

\section{Ammonium regeneration}

Heterotrophic flagellates do not in general assimilate ammonium, but as part of the microbial loop they regenerate ammonium and will indirectly affect the autotrophic ammonium uptake. This was demonstrated in the same area by Ferrier \& Rassoulzadegan (1991), in that APF and ANF exhibited enhanced growth in the presence of heterotrophic protozoa, and in our results, since HPF and HNF were significantly correlated with ammonium uptake at the same level as the autotrophic organisms. In spite of this, the observed rates of ammonium regeneration were very variable (Fig. 9). 
On 17 May, when the autotrophic organisms $<1 \mu \mathrm{m}$ dominated and the grazers in the $1-10 \mu \mathrm{m}$ size interval were absent, ammonium regeneration was negligible. By 30 May, a reasonable time lapse for heterotrophic adaptation to changes in prey densities (McManus \& Fuhrman 1988), the ammonium regeneration had increased to the highest rates observed during this study. This coincided with a high abundance of ciliates, also in the $1-10 \mu \mathrm{m}$ size interval. The only other observation of a large ciliate biovolume was on 9 November, but no regeneration experiments were performed at that time. The in situ concentrations of ammonium (Table 1), however, indicated a substantial ammonium regeneration. In April, the ammonium regeneration was caused by the $<1 \mu \mathrm{m}$ size class, and thus presumably by heterotrophic bacteria and HPF. In these experiments, the heterotrophic bacteria seem more likely to assimilate ammonium, and thus this result could be an artifact due to the release of dissolved organic material during the pre-fractionation which could have stimulated ammonium regeneration (Fuhrman \& Bell 1985). The high ammonium regeneration rates on 4 December (in the plankton $>10 \mu \mathrm{m}$ ) cannot be explained in view of the biological composition.

There are some inconsistencies in our results from 15 April and 30 May, since the smaller size fractions exhibited higher regeneration rates than those of the larger fractions. This phenomenon was recently discussed by Glibert et al. (1992), who explained it by trophic alterations due to the pre-fractionation. With the ${ }^{15} \mathrm{~N}$-isotope methods available today, prefractionation is necessary but could cause a reduction in the grazing pressure on the heterotrophic organisms, and thus increase the regeneration rate (Glibert et al. 1992).

The ratio between the regeneration and uptake rates of ammonium was always well in excess of unity, except for $17 \mathrm{May}$, when the heterotrophic grazers were absent (see above). This could be due to either a heterotrophic dominated ecosystem or diel variations. In the latter case, regeneration and uptake would balance on a longer time scale. Although the Mediterranean Sea is considered to have elevated $\mathrm{C}: \mathrm{N}$ ratios relative to other oceans (Béthoux \& CopinMontégut 1986, Dugdale \& Wilkerson 1988), the C:N ratios observed here were well above the Redfield ratio of 6.6 (Redfield et al. 1963), and indicates particulate organic material consisting not only of living plankton but also detritus. The ratio between PN and chl a has also been used as an index of the quality of particulate material. A PN:chl a ratio close to unity indicates particulate material consisting mainly of phytoplankton, while elevated ratios are an indication of detritus and/or heterotrophs and high grazing pres- sure (McCarthy \& Nevins 1986, Wheeler \& Kokkinakis 1990). For the unfractionated water, PN:chl a was in the range of 2.3 to 3.8 . Thus, considering the data on particulate organic material and chl $a$, the ecosystem seems to have consisted of a substantial portion of detritus and/or heterotrophs. Since detritus was not observed in the microscope, and since the heterotrophic bacteria constituted a substantial part of the plankton, the latter explanation seems most plausible. This would also be indicative of a high grazing pressure, as seen in the dominating ammoniun uptake and relative high ammonium regeneration rates.

\section{New and regenerated production}

The $f$-ratio, defined as new production : total production (Eppley \& Peterson 1979), was in our studies of the magnitude of 0 to 0.02 , except for 30 November when $f=0.34$ (calculated for unfractionated water). Using $f=0.02, r(=(1-f) / f)$, which is the number of times nitrogen will be recycled within the photic zone before being exported (Eppley \& Peterson 1979), becomes 49. These numbers imply an ecosystem completely (98 to $100 \%$ ) based on regenerated production.

The percentages of new production reported here (0 to $2 \%$ ) were much lower than those reported earlier from the Ligurian Sea of ca $25 \%$ new production, and which were based on indirect calculations and sediment traps (Minas et al. 1988, Fowler et al. 1991). According to Dugdale \& Wilkerson (1988), however, it is perhaps incorrect to use the concept of new and regenerated production in the Mediterranean Sea due to external sources of ammonium. Thus, if autochtonous and allochtonous ammonium inputs to the photic zone cannot be separated, sedimentation rates measured over a sufficiently long period could be a better way of estimating new production. However, due to the very low ambient concentrations of ammonium, and the large difference between $0-2$ and $25 \%$ in new production, we do not believe that an allochtonous ammonium input can explain this difference. The importance of regenerated nutrients in this ecosystem is also evident in the occasionally high ammonium regeneration rates and the highly significant correlation between the abundance of heterotrophic flagellates and ammonium uptake rates.

Considering the predominance of regenerated production in our studies, we cannot agree with the conclusion of Fowler et al. (1991) that the Ligurian Sea is eutrophic instead of oligotrophic. Our studies were performed in the Bay of Villefranche-sur-Mer which is part of the Ligurian Sea, but relatively close to land. As mentioned above, the sampling station is regarded as coastal temperate waters. Taking the biological composition into 
account, pico- and nanoplankton generally seem to accomplish an equal share of the ammonium uptake. Earlier observations of size-fractionated ammonium uptake have demonstrated the importance of nanoplankton in more eutrophic waters (e.g. Glibert et al. 1982a, Probyn 1987), while the picoplankton dominates in the oligotrophic regions (e.g. Probyn 1985, Probyn \& Lucas 1987. Glibert et al. 1988). This gives us reason to characterize these waters (i.e. Point $B$ ) as intermediate with respect to production, and thus mesotrophic

Acknowledgements. We thank Alain Gosjon for giving us the opportunity of analyzing our ${ }^{15} \mathrm{~N}$-samples at ENSA-M/INRA in Montpellier, and for his valuable help during our work there; Juan Carlos Miquel at IAEA, Monaco, and Patrick Raimbault at Centre d'Oceanologie, Marseille, for their help with CHN-analysis; Marie Dominique Pizay for analyzing the nitrate samples; and 3 anonymous reviewers for valuable comments. This work was supported by NFR-CNRS convention grants and CNRS URA 716 grant.

\section{LITERATURE CITED}

Andersen, P. (1988). The quantitative importance of the 'microbial loop' in the marine pelagic: a case study from the North Bering/Chukchi seas. Arch. Hydrobiol Beih. Ergebn. Limnol. 31: 243-251

Azam, F., Fenchel, T., Field, J. C., Grey, J. S., Meyer-Reil, L.-A., Thingstad, F. (1983). The ecological role of watercolumn microbes in the sea. Mar Ecol. Prog. Ser 10: $257-263$

Berland, B. R., Bezhitski, A. G., Burla-Kova, Z. P., Geogieva, L. V., Izmestieva, M. A., Kholodov, V l., Maestrini, S. Y (1988). Conditions hydrologiques estivales en Méditerranée, repartition du phytoplancton et de la matiére organique. In: Minas, H. J., Nival, P. (eds.) Océanographie pélagique méditerranéenne. Oceanol. Acta sp vol. 9: $87-94$

Béthoux, J. P., Copin-Montégut, G. (1986). Biological fixation of atmospheric nitrogen in the Mediterranean Sea. Limnol. Oceanogr. 31: 1353-1358

Blackburn, T. $\mathrm{H}$. (1979). Method for measuring rates of $\mathrm{NH}_{4}{ }^{+}$ turnover in anoxic marine sediments, using a ${ }^{15} \mathrm{~N}-\mathrm{NH}_{4}{ }^{+}$ dilutiuon technique. Appl environ. Microbiol. 37: 760-765

Caperon, J., Schell, D., Hirota, J., Laws, E. (1979). Ammonium excretion rates in Kaneohe Bay, Hawaii, measured by a ${ }^{15} \mathrm{~N}$ isotope dilution technique. Mar. Biol. 54: 33-40

Chisholm, S. W., Olson, R. J., Zettler, E. R., Goericke, R., Waterbury, J. B., Welschmeyer, N. A. (1988). A novel freeliving prochlorophyte abundant in the oceanic euphotic zone. Nature 334: 340-343

Cruzado, A., Velásquez, Z. R. (1989). Nutrient distributions in the Gulf of Lions, winter 1989. In: Martin, J. M., Barth, H. (eds.) EROS 2000 (European River Ocean System), project workshop. CEC Water Pollut. Res. Rep. 13, p. 67-78

Dugdale, R. C. (1976). Nutrient cycles. In: Cushing, D. H. (ed.) The ecology of the sea. Blackwell, Oxford, p. 141-177

Dugdale, R. C., Goering, J. J. (1967). Uptake of new and regenerated forms of nitrogen in primary productivity. Limnol. Oceanogr. 12: 196-206

Dugdale, R. C., Wilkerson, F. P. (1986). The use of ${ }^{15} \mathrm{~N}$ to measure nitrogen uptake in eutrophic oceans; experimental considerations. Limnol. Oceanogr. 31: 673-689
Dugdale, R. C., Wilkerson, F. P. (1988). Nutrient sources and primary production in the Eastern Mediterranean. In: Minas, H. J., Nival, P. (eds.) Océanographie pélagique méditerranéenne. Oceanol. Acta sp. vol. 9:179-184

Eppley, R. W., Peterson, B. J. (1979). Particulate organic matter flux and planktonic new production in the deep ocean. Nature 282: 677-680

Ferrier, C., Rassoulzadegan, F. (1991). Density-dependent effects of protozoans on specific growth rates in picoand nanoplanktonic assemblages. Limnol. Oceanogr. 36 : $657-669$

Fowler, S. W., Small, L. F, La Rosa, J. (1991). Seasonal particulate carbon flux in the coastal northwestern Mediterranean Sea, and the role of zooplankton fecal matter. Oceanol. Acta 14: 77-85

Fuhrman, J. A., Bell, T. M. (1985). Biological considerations in the measurement of dissolved free amino acids in seawater and implications for chemical and microbiological studies. Mar. Ecol. Prog. Ser. 25: 13-21

Glibert, P. M., Goldman, J. C., Carpenter, E. J. (1982a). Seasonal variations in the utilization of ammonium and nitrate by phytoplankton in Vineyard Sound, Massachusetts, USA. Mar. Biol. 70: 237-240

Glibert, P. M., Lipschultz, F., McCarthy, J. J., Altabet, M. A. $(1982 b)$. Isotope dilution models of uptake and remineralization of ammonium by marine plankton. Limnol. Oceanogr. 27: 639-650

Glibert, P. M., Dennett, M. R., Caron, D. A. (1988). Nitrogen uptake and $\mathrm{NH}_{4}^{+}$regeneration by pelagic microplankton and marine snow from the North Atlantic. J. mar. Res. 46: $837-852$

Glibert, P. M, Miller, C. A., Garside, C., Roman, M. R., McManus, G. B. (1992). $\mathrm{NH}_{4}{ }^{+}$regeneration and grazing: interdependent processes in size-fractionated ${ }^{15} \mathrm{NH}_{4}{ }^{+}$ experiments. Mar. Ecol. Prog. Ser. 82: 65-74

Goldman, J. C., Caron, D. A., Dennett, M. R. (1987). Regulation of gross growth efficiency and ammonium regeneration in bacteria by substrate $\mathrm{C}: \mathrm{N}$ ratio. Limnol. Oceanogr. 32: $1239-1252$

Goldman, J. C., Dennett, M. R. (1991). Ammonium regeneration and carbon utilization by marine bacteria grown on mixed substrates. Mar. Biol. 109: 369-378

Hagström, §., Azam, F., Andersson, A., Wikner, J., Rassoulzadegan, F. (1988). Microbial loop on an oligotrophic pelagic marine ecosystem: possible roles of cyanobacteria and nanoflagellates in the organic fluxes. Mar. Ecol. Prog. Ser. 49: 171-178

Harrison, W. G., Wood, L. J. E. (1988). Inorganic nitrogen uptake by marine picoplankton: Evidence for size partitioning. Limnol. Oceanogr. 33: 468-475

Holligan, P. M., Williams, P. J. leB., Purdie, D., Harris, R. P. (1984). Photosynthesis, respiration and nitrogen supply of plankton populations in stratified, frontal and tidally mixed shelf waters. Mar. Ecol. Prog. Ser. 17: 201-213

Joint, I. R., Owens, N. P. J., Pomroy, A. J. (1986). The seasonal production of picoplankton and nanoplankton in the Celtic Sea. Mar. Ecol. Prog. Ser. 28: 251-258

Kristiansen, S., Paasche, E. (1982). Preparation of ${ }^{15} \mathrm{~N}$ labelled phytoplankton samples for optical emission spectrometry. Limnol. Oceanogr. 27: 373-375

Krom, M. D., Kress, N., Brenner, S., Gordon, I. (1991a). Phosphorus limitation of primary productivity in the eastern Mediterranean Sea. Limnol. Oceanogr. 36: 424-432

Krom, M. D., Brenner, S., Israelov, L., Krumgalz, B. (1991b). Dissolved nutrients, preformed nutrients and calculated elemental ratios in the South-Eastern Mediterranean Sea. Oceanol. Acta 14: 189-194 
Li, W. K. W (1990). Particles in 'particle-free' seawater: growth of ultraphytoplankton and implications for dilution experiments. Can. J. Fish. Aquat. Sci. 47: 1258-1268

Lins Da Silva, N. M. (1991). Etude de la répartition spatiotemporelle des peuplements microbiens planctoniques en Mer Ligure (Med.). Ph.D. thesis, University of P. et M. Curie, Paris

Lorenzen, C. J. (1966). A method for continuous measurement of in vivo chlorophyll concentrations. Deep Sea Res. 13: 223-227

Maestrini, S., Kossut, M.-G. (1981). In situ cell depletion of some marine algae enclosed in dialysis sacks and their use for the determination of nutrient-limiting growth in Ligurian coastal waters (Mediterranean Sea). J. exp. mar. Biol. Ecol. 50: 1-19

Martin, J.-M., Elbaz-Poulichet, F., Guieu, C., Loÿe-Pilot, M.-D., Han, G. (1989). River versus atmospheric input of material to the Mediterranean Sea: an overview. Mar. Chem. 28: 159-182

McCarthy, J. J., Nevins, J. L. (1986). Sources of nitrogen for primary production in warm-core rings $79-\mathrm{E}$ and $81-\mathrm{D}$. Limnol. Oceanogr. 31: 690-700

McManus, G. B., Fuhrman, F. A. (1988). Control of marine bacterioplankton populations: measurement and significance of grazing. Hydrobiologia 159: 51-62

Minas, H. J., Minas, M., Coste, B., Gostan, J., Nival, P., Bonin, M.-C. (1988). Production de base et de recyclage; une revue de la problématique en Méditerranée nordoccidentale. In: Minas, H. J., Nival, P. (eds.) Océanographie pélagique méditerranéenne. Oceanol. Acta sp. vol. 9: $155-162$

Neveux, J., Vaulot, D., Courties, C., Fukai, E. (1989). Green photosynthetic bacteria associated with the deep chlorophyll maximum of the Sargasso Sea. C. r. Acad. Sci. Paris 308 (III): $9-14$

Owens, N. J. P., Rees, A. P., Woodward, E. M. S., Mantoura, R. F. C. (1989). Size-fractionated primary production and nitrogen assimilation in the northwest Mediterranean Sea during Januery 1989. In: Martin, J. M, Barth, H. (eds.) EROS 2000 (European River Ocean System), project workshop. CEC Water Pollut. Res. Rep. 13, p 126-135

Platt, T., Li, W. K. W. (eds.) (1986). Photosynthetic picoplankton. Can. Bull. Fish. Aquat. Sci. 214

Pomeroy, L. R. (1974). Oceanic productivity: a changing paradigm. BioSci. 24: 499-501

Probyn, T A. (1985). Nitrogen uptake by size-fractionated phytoplankton populations in the southern Benguela upwelling system. Mar. Ecol. Prog. Ser. 22: 249-258

Probyn, T. A. (1987). Ammonium regeneration by microplankton in an upwelling environment. Mar. Ecol. Prog. Ser. 37: 53-64

Probyn, T. A., Lucas, M. I. (1987). Ammonium and phosphorus flux through the microplankton community in Agulhas Bank waters. S. Afr. J. mar. Sci 5: 209-221

Probyn, T A., Waldron, H. N., James, A. G. (1990). Sizefractionated measurements of nitrogen uptake in aged upwelled waters: implications for pelagic food webs. Limnol. Oceanogr. 35: 202-210

Rassoulzadegan, F. (1977). Evolution annuelle des ciliés pélagiques en Méditerranée Nord Occidentale. Ciliés oligotriches non tintinnides. Ann. Inst. Océanogr., Paris 53: $125-134$

Rassoulzadegan, F. (1979). Cycles annuels de la distribution des différentes catégories de particules de seston et essai d'identification des principales poussées phytoplanctoniques dans les eaux néritiques de Villefranche-surMer. J. exp. mar. Biol. Ecol. 38: 41-56
Rassoulzadegan, F, (1990). Marine protozooplankton and food webs. Zool. Sci. 7: 189-196

Rassoulzadegan, F., Gostan, J. (1976). Répartition des ciliés pélagiques dans les eaux de Villefranche-sur-Mer. Remarques sur la dispersion du microzooplancton en mer et à l'intérieur des échantillins dénombres par la méthode d'Utermöhl. Ann. Inst. Océanogr., Paris 52: 175-188

Rassoulzadegan, F., Sheldon, R. W. (1986). Predator-prey interactions of nanozooplankton and bacteria in an oligotrophic marine environment. Limnol. Oceanogr. 31: $1010-1021$

Redfield, A. C., Ketchum, B. H., Richards, F. A. (1963). The influence of organisms on the composition of sea-water. In: Hill, M. N. (ed.) The sea. Vol. 2, Wiley, New York p. $26-77$

Ricard, M. (1987). Atlas du phytoplancton marin, Vol. 2 Edition du CNRS, Paris

Selmer, J.-S. (1988). Ammonium regeneration in the marine environment. Ph.D. thesis, University of Göteborg, Göteborg

Selmer, J.-S, Sörensson, F. (1986). New procedure for the extraction of ammonium from natural waters for ${ }^{15} \mathrm{~N}$ Isotope ratio determination. Appl. environ. Microbiol. 52: $577-579$

Sheldon, R. W., Rassoulzadegan, F. (1987). A method for measuring plankton production by particle counting. Mar. Microb. Food Webs 2: 29-44

Sherr, E. B., Sherr, B. F., Berman, T., McCarthy, J. J. (1986). Phagotrophic protozoa as food for metazoans: 'a missing' trophic link in marine pelagic food webs. Mar. Microb. Food Webs 1: 61-80

Smetacek, V. (1981). The annual cycle of protozooplankton in Kiel Bight. Mar. Biol. 63: 1-11

Sournia (1986). Atlas du phytoplancton marin, Vol. 1. Edition du CNRS, Paris

Stockner, J. G., Klut, M. E., Cochlan, W. P. (1990). Leaky filters: a warning to aquatic ecologists. Can. J. Fish. Aquat. Sci. 47: 16-23

Strickland, J. D., Parsons, T R. (1972). A practical handbook of seawater analysis, 2nd edn. Bull. Fish. Res. Bd Can. 167

Takahashi, M., Bienfang, P. K. (1983). Size structure of phytoplankton biomass and photosynthesis in subtropical Hawaiian waters. Mar. Biol. 76: 203-211

Tréguer, P., Le Corre, P. (1975). Manuel d'analyse des sels nutritifs dans l'eau de mer (utilisation de l'Autoanalyzer II Technicon). Laboratoire d'Océanographie chimique, Université de Bretagne Occidentale, $2^{c}$ éd., Brest

Utermöhl, H. (1958). Zur Vervollkommung der quantitativen Phytoplankton Methodik. Mitt. int. Ver. Limnol. 9: 1-38

Vaulot, D., Partensky, F. (1992). Cell cycle distributions of prochlorophytes in the north western Mediterranean Sea. Deep Sea Res. 39: 727-742

Vaulot, D., Partensky, F., Neveux, J., Mantoura, R. F. C., Llewellyn, C. A. (1990). Winter presence of prochlorophytes in surface waters of the northwestern Mediterranean Sea. Limnol. Oceanogr. 35: 1156-1164

Wheeler, P. A., Kirchman, D. L. (1986). Utilization of inorganic and organic nitrogen by bacteria in marine systems. Limnol. Oceanogr. 31. 998-1009

Wheeler, P. A., Kokkinakis, S. A. (1990). Ammonium recycling limits nitrate use in the oceanic subarctic Pacific. Limnol. Oceanogr. 35: 1267-1278

Wiadnyana, N. N. (1991). Estimation du transfert de matiéres entre le réseau microbien pélagique et les consommateurs meso- et macroplanctoniques - écosystème oligotrope (Mer Ligure). Ph.D. thesis, University of P. et M. Curie, Paris 
Williams, P. J. leB. (1981). Incorporation of microheterotrophic processes into the classical paradigm of the planktonic food web. Kieler Meeresforsch., Sonderh. 5: 1-28

Woodward, E. M. S., Owens, N. J. P. (1989). The influence of the River Rhone upon the nutrient fluxes of the Golfe du Lion. In: Martin, J. M., Barth, H. (eds.) EROS 2000 (European River Ocean System), project workshop. In:

This article was presented to the editor
CEC Water Pollut. Res. Rep. 13, p. 79-86

Woodward, E. M. S., Owens, N. J. P., Rees, A. P., Law, C. S. (1990). A seasonal survey of nutrient cycling and primary productivity in the Gulf of Lions, during 1988 and 1989. In: Martin, J. M., Barth, H. (eds.) EROS 2000 (European River Ocean System), 2nd Workshop on the NW Mediterranean Sea, Blanes, Spain, 6-9 Feb 1990

Manuscript first received: January 13, 1993

Revised version accepted: June 28, 1993 